\title{
ВДОСКОНАЛЕННЯ ТЕХНОЛОГІЇ РОЗРАХУНКУ ПОКАЗНИКІВ ЕКСПЛУАТАЦИЙНОЇ РОБОТИ З ВИКОРИСТАННЯМ АВТОМАТИЗОВАНОЇ СИСТЕМИ
}

\begin{abstract}
В умовах розвитку транспортного ринку ключовими питаннями для системи залізничних перевезень є: своєчасне забезпечення вагонами відповідного типу усіх відправників вантажу відповідно до їх замовлень; подальше закріплення залізничного транспорту на ринку перевезень шляхом розвитку маркетингу, створення збалансованої тарифної політики; удосконалення організаційних структур управління залізничним транспортом, технології перевізного процесу та організації перевізної роботи на основі широкого впровадження автоматизованих систем управління. Мета статті полягає у дослідженні можливості підвищення ефективності використання парку вагонів, пов'язаного з цим дотримання термінів доставки вантажу, на базі нової методики та принципу розрахунку. Один з основних комплексних показників роботи залізниці є обіг вагону, що відображає час повного циклу роботи вагону. Наразі обіг вагону збільшується, для залізниці це означає невиконання встановлених норм, для отримувачів послуг - клієнтів залізниці - це означає прострочення термінів доставки вантажу, порушення фінансових зобов'язань перед іншими учасниками процесу перевезень. Інформаційні технології залізниці обумовлюють можливість контролю за виконанням нормативу обігу вагону та дотриманням термінів доставки вантажу 3 подальшим вдосконаленням методик та методів визначення показників експлуатаційної роботи. Досліджено підвищення ефективності використання парку вагонів, пов'язаного з цим дотримання термінів доставки вантажу, за рахунок нової методики та принципу розрахунку і прогнозу основних показників роботи. Проаналізовано можливості відійти від умовного визначення обігу за формулами, що використовують балансовий метод та застосовувати сучасні статистичні методи для визначення обігу вагонів як характеристики певного перевезення. Це дозволить встановлювати реальні норми обігу вагонів та терміни доставки вантажів, що забезпечать дотримання технологічних процесів експлуатаційної роботи залізниці при обслуговуванні клієнтів.

Ключові слова: інформаційні технології, терміни доставки, обіг вагонів, технологічний процес,
\end{abstract} залізниця.

\section{ВСТУП}

Основними аспектами стратегії розвитку залізниці України є дотримання термінів доставки вантажів, прискорення обігу вагонів та удосконалення системи управління на базі інформаційних технологій. Виконання термінів доставки вантажів та дотримання норм обігу вагонів, на нашу думку, $\epsilon$ ознакою досконалого технологічного процесу, за яким організована експлуатаційна робота. На жаль, на поточний період, і за попередні роки, обіг вагонів постійно збільшується, про що констатують звіти залізниці та дослідження фахівців [8-12]. Невиконання норм обігу вагонів та термінів доставки вантажів вказує на недотримання технології процесів. Крім того, існує значна різниця між плановими та виконаними показниками обігу вагону. Це свідчить про необхідність розробки нових методик та принципів розрахунку, і прогнозу основних показників роботи. Наразі фахівцями розглядаються різні шляхи вирішення задачі адекватного прогнозування процесів перевезення з урахуванням існуючих умов експлуатаційної роботи [1], що дозволить встановлювати реальні терміни доставки вантажів та норми обігу вагонів. Фахівцями-практиками також ставляться задачі зміни принципів нормування при плануванні перевезень з метою виконання термінів доставки вантажів, прискорення обігу вагонів та удосконалення системи управління [2]. Ефективне використання транспортних засобів, прискорення оборотності вагонів, також розглядається у роботах [3, 13-17], присвячених оптимізації виробництва промислових підприємств .

\section{АНАЛІЗ ЛІТЕРАТУРНИХ ДАНИХ ТА ПОСТАНОВКА ПРОБЛЕМИ}

Як відомо, середній (умовний) обіг вагона для мережі залізниць визначається діленням робочого парку вагонів на середньодобове навантаження [4, с.24], а обіг вагона за елементами [4, с.50] визначається за формулою:

$$
O_{v}=\frac{l}{24} \cdot\left(\frac{1}{V_{d}}+\frac{1}{L_{t e x}} \cdot t_{t e x}+k \cdot t_{v a n}\right)
$$

де ${ }^{l}$ - повний рейс вагона, км;

$v_{\text {д }}$ - середня дільнична швидкість вагона, км/год.; 
$L_{\text {mex }}$ - вагонне плече, км;

$T_{m e x}$ - середній простій вагона на одній технічній станції, км;

$k$ - коефіцієнт місцевої роботи;

$t_{\text {ван }}$ - середній простій вагона на одній станції з вантажними операціями, год.

Вочевидь, певні характеристики перевізного процесу не враховані у наведених формулах, тому i фактичне виконання обігу вагонів значно перевищує нормативи. Так, існуючи формули не враховують час ремонту вагонів, хоча технічний стан вагонного парку суттєво впливає на час циклу роботи вагона. Це є одно з пояснень невиконання запланованого обігу вагонів і постійного його збільшення наразі [5].

Аналогічні задачі існують і в залізничних адміністраціях сусідніх держав (ОАО "РЖД", СНД, країни Балтіі). В формули розрахунків обігу фахівцями вводяться коефіцієнти, що оцінюються експертами та використовується прогнозування [6].

В той же час інформаційна система (IT) залізниці (АСК ВП УЗ-С) являє собою гігантське сховище даних, що описують виконану роботу, констатує процеси, що відбулись [7[ і містить всі операції з кожним вагоном. Це означає, що існує можливість розрахунку обігу кожного вагону чи розрахунку групи вагонів за якимось окремими характеристиками. Аналогічно у автоматизованій системі наразі розраховується час знаходження кожного вагону під вантажними операціями (для оплати клієнтом), що є однією із складових частин обігу вагону.

При розробці нової методики 3 визначення показників роботи залізниці запропоновано врахувати наступне:

-не розраховувати обіг за існуючими застарілими формулами, а встановлювати обіг вагону, виходячи з фактичної роботи, що відображається у базі даних АСКВП УЗ-С;

-обіг вагонів пропонується розраховувати за родом рухомого складу при перевезенні певного роду вантажу (у т.ч.), тобто визначати обіг вагону як показник обслуговування певного вантажопотоку;

-якщо на території однієї із залізниць здійснюється неповний цикл роботи вагону, розраховувати долю (залізниці) в обігу (повному циклі від навантаження до наступного навантаження);

-за даними обігу та роботи слід розраховувати необхідний робочий парк вагонів для перевезення визначеного вантажу у визначеному рухомому складі.

\section{РЕЗУЛЬТАТИ ДОСЛІДЖЕНЬ}

3 метою аналізу показника обігу вагонів у процесах перевезень вантажів були оброблені дані про транспортування маршрутів (та групових відправок) з чорними металами 3 Кривого Рогу до Одеського порту за декількома маршрутам слідування. Для аналізу даних розроблено таблицю норм руху поїзду за графіком по визначеним станціям маршруту, з урахуванням часу обробки на стикових пунктах та станціях зміни тяги або локомотива.

Дані про час слідування вагонів від початкової станції маршруту до станції призначення складають частину показника - обіг вагонів. Продовження циклу роботи вагонів - це час знаходження вагонів на під’їзній колії, що визначається операціями у IT з умовною позначкою «ПОГР» або «ВЫГР» (аналізується час здійснення операції). I третю складову частину обігу вагонів додає час слідування під наступне навантаження або вивантаження.

Проаналізовано цикл роботи вагонів при здійсненні технологічних операцій:

Залізниця навантаження вагона - Придніпровська, вивантаження - Одеська залізниця, наступне навантаження - Придніпровська.

Залізниця навантаження вагона - Придніпровська, вивантаження - Одеська залізниця, наступне навантаження - Одеська.

Залізниця навантаження вагона - Придніпровська, вивантаження - Одеська залізниця, наступне навантаження вагону з новим вантажем здійснюється на третій (не Придніпровській, не Одеській) залізниці.

Обіг вагонів залежить від багатьох факторів - зокрема від періоду року (Рис.1). 


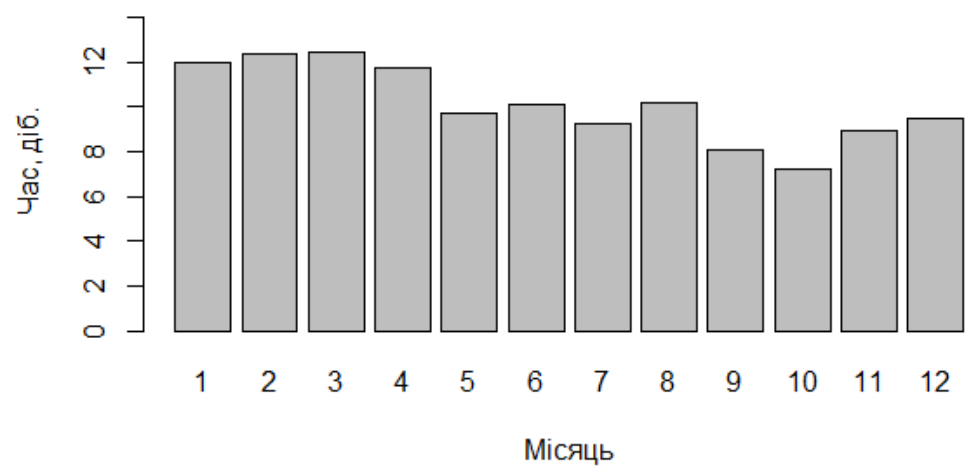

Рисунок 1 - Середній час обігу за місяць

Встановлено, що протягом перших трьох кварталів - зниження медіани, середнього значення, третього квартиля та, особливо, - верхньої межі. В четвертому кварталі - деяке зростання названих показників. Помітна незначна динаміка першого квартиля та певні флуктуації нижньої межі (Рис.2).

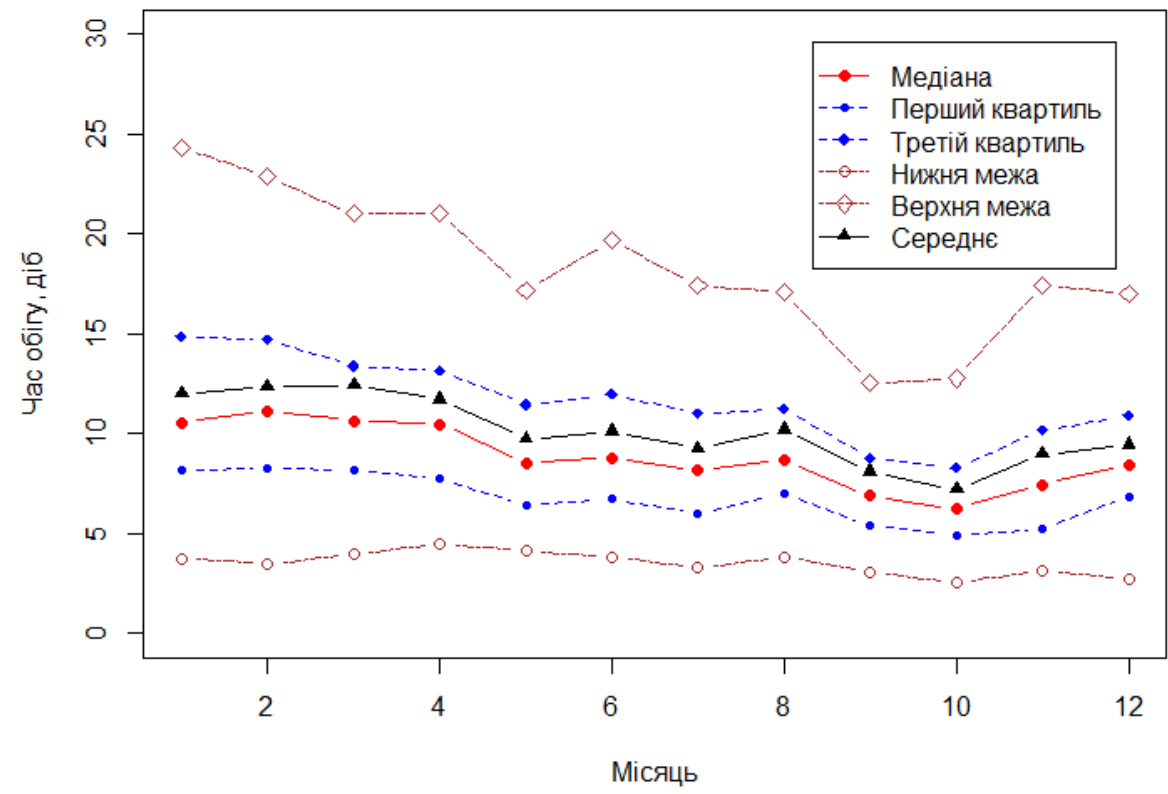

Рисунок 2 - Динаміка часу обігу

Загальні характеристики випадків Придніпровська- Придніпровська (Кількість вагонів - 1632) (Рис.3, 4)).

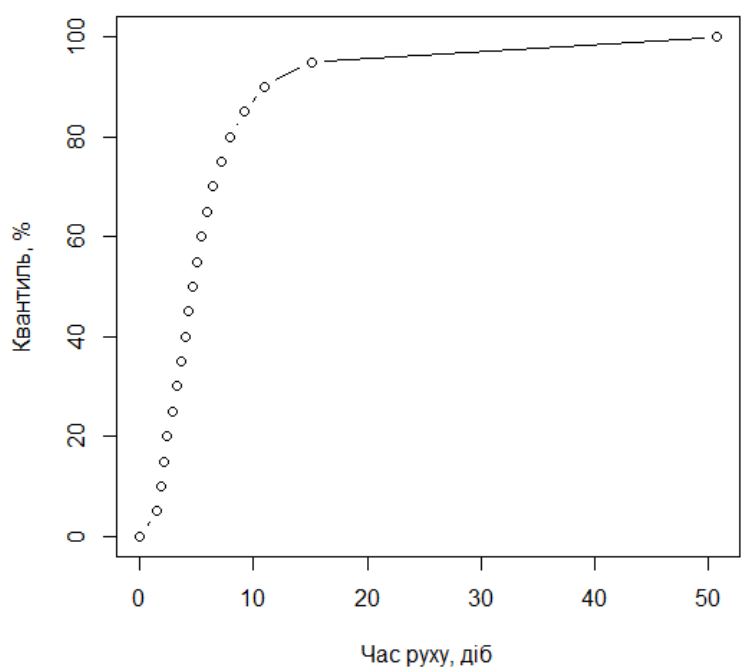

Рисунок 3 - Квантилі часу руху по Придніпровській залізниці 


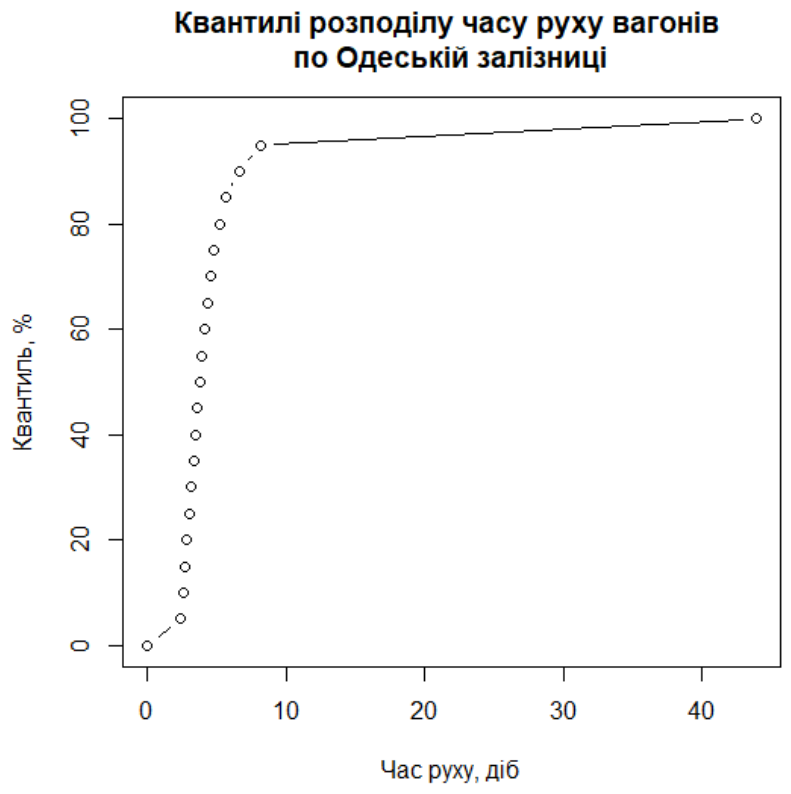

Рисунок 4 - Квантилі розподілу часу руху по Одеській залізниці

3 порівняння наявних даних видно, що серед вагонів з часом руху до трьох діб як на Одеській, так і на Придніпровській залізниця рухалося близько 30 \% від їх загального числа. Проте на менших часових інтервалах Придніпровська залізниця виявляла більшу оперативність, так для $10 \%$ вагонів 3 найменшим часом руху на Придніпровській він не перевершував 1.8 діб, а на Одеській -2.58 діб.

Проте на більших часових інтервалах вагони швидше рухались на Одеській залізниці $t_{0.5}^{O D}=3.74 \Pi р о т и ~ t_{0.5}^{I D}=4.65$ на Придніпровській, тобто медіана на Одеській залізниці менша на майже на добу (0.91 доби). А вже 90-й процентиль часу руху по Одеській залізниці на 4,32 доби менший відповідного значення для Придніпровської залізниці (Рис.5).

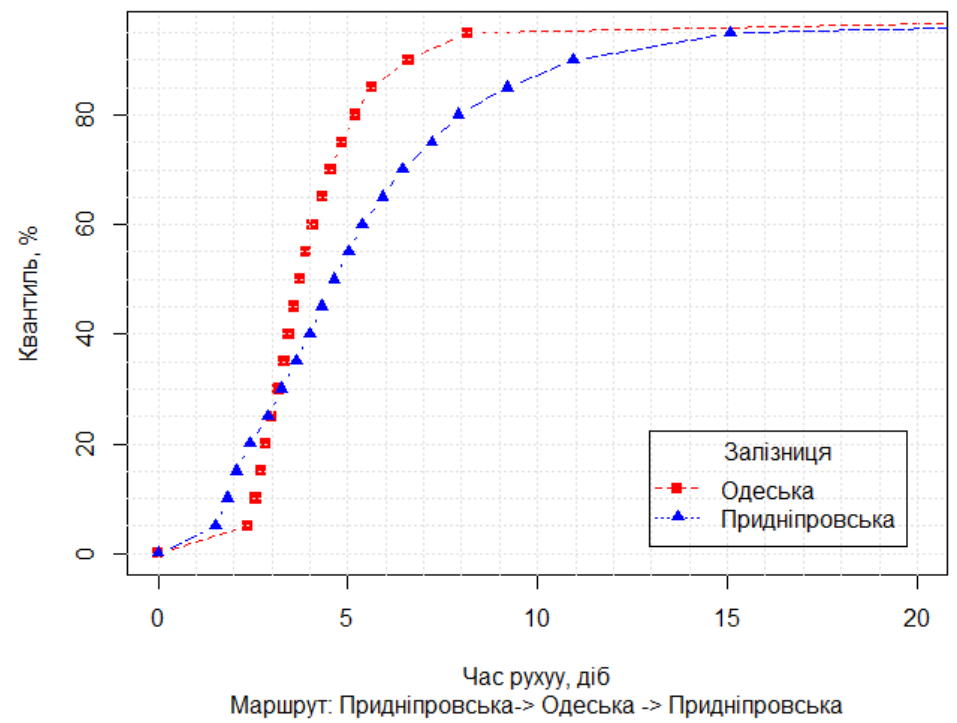

Рисунок 5 - Квантилі розподілу часу руху вагонів

\section{ОБГОВОРЕННЯ РЕЗУЛЬТАТІВ ДОСЛІДЖЕНЬ}

Для аналізу часу знаходження вагонів на залізницях (під час виконання циклу)введемо логічну змінну $b_{1}=t^{\text {od }}>$ bound $^{\text {od }}$, яка приймає значення «true» у випадку, якщо час руху вагона по Одеській

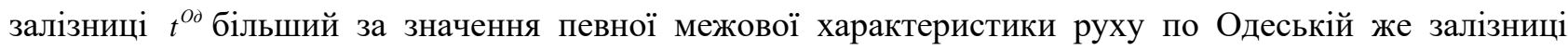
bound $^{\text {od }} .3$ аналогічною метою для Придніпровської залізниці введемо змінну $b_{2}=t^{\Pi_{p}}>$ bound $d^{\Pi p}$.

Замість bound $^{\text {Od }}$ та bound ${ }^{\Pi p}$ будемо писати bound ${ }^{X}$, де $X \in\{O \partial, \Pi p\}$.

У таблиці 1 наведено дані про структуру вибірки вагонів відносно межової характеристики pyxу вагонів bound $^{X}$ зі значеннями 25-го процентиля, медіани, середнього значення та 75-го процентиля. 
Будемо говорити, що вагон відноситься до вагонів типу 1, якщо час його знаходження на Одеській залізниці перевершує значення bound $^{\text {od }}$, вказане у рядку таблиці, тільки на Одеській залізниці, але не на Придніпровській (тобто на Придніпровській той же вагон має менший час руху, ніж значення bound $d^{I p}$ ) . До вагонів типу 2 - ті, час руху яких перевершує значення bound $d^{I p}$ навпаки тільки на Придніпровській залізниці, а на Одеській час руху менший за bound $^{\text {od }}$. Вагони типу 3 — це вагони, час руху яких більший за bound $^{X}$ на кожній із залізниць. I, нарешті, тип 4 - це вагони, час pyху яких не перевершує bound $^{X}$ на кожній із залізниць.

Таблиця 1. Дані про структуру вибірки вагонів відносно межової характеристики руху вагонів

\begin{tabular}{|c|c|c|c|c|c|}
\hline № рядка & bound $^{X}$ & $\begin{array}{c}1, \% \\
b_{1} \wedge \overline{b_{2}}\end{array}$ & $\begin{array}{c}2, \% \\
\overline{b_{1}} \wedge b_{2}\end{array}$ & $\begin{array}{c}3, \% \\
b_{1} \wedge b_{2}\end{array}$ & $\begin{array}{c}4, \% \\
b_{1} \wedge \overline{b_{2}}\end{array}$ \\
\hline 1 & $t_{0.25}^{X}$ & 17,8 & 18 & 57 & 7,2 \\
\hline 2 & $t_{0.50}^{X}=$ median $^{X}$ & 24,6 & 24,6 & 25,4 & 25,4 \\
\hline 3 & mean $^{X}$ & 21.93 & 21.93 & 13.23 & 42.89 \\
\hline 4 & $t_{0.75}^{X}$ & 18,8 & 18.3 & 6.7 & 56,7 \\
\hline
\end{tabular}

Кожен вагон вибірки потрапляє тільки до одного типу, а об'єднання цих чотирьох типів вагонів становить повну вибірку.

Кількість вагонів типу 1 та 2 , як це видно з Таблиці 1 , дуже близькі для різних значень bound $^{x}$. Разом вони дають уявлення про кількість вагонів, які перевершили відповідну межу bound $^{X}$ тільки на одній із залізниць.

Так у рядку № 2 таблиці бачимо, що майже 50 відсотків вагонів $(49,2 \%)$ потрапили до половини вагонів 3 найбільшим часом руху (більшим за медіану на відповідній залізниці) тільки із-за проблем на одній із залізниць. Можливо, спільні проблеми призвели до того, що 25,4\% вагонів мали час руху, більший за медіану на обох залізницях одночасно - тип 3 . Час руху решти $25,4 \%$ вагонів, менший за медіану для кожної із залізниць.

Щодо вагонів 3 bound ${ }^{X}=$ mean $^{X}$, див. рядок № 3 таблиці, легко помітити, що понад 57\% вагонів мають час руху, більший за середнє значення руху на відповідній залізниці. При цьому із-за проблем однієї з залізниць - майже $44 \%$, та понад $13 \%$ - 3 одночасним для обох залізниць перевершенням середнього значення часу руху.

Отже, частка вагонів, затримку яких спричинила тільки одна залізниця, становить від 35,8\% до $49,2 \%$.

Подібні розрахунки для вагонів, час обігу яких перевершує медіану часу обігу за вказаним маршрутом (8,771 діб), наведені у табл. 2.

Таблиця 2. Розрахунки для вагонів, час обігу яких перевершує медіану часу обігу

\begin{tabular}{|c|c|c|c|c|c|}
\hline № рядка & bound $^{X}$ & $\begin{array}{c}1, \% \\
b_{1} \wedge \overline{b_{2}}\end{array}$ & $\begin{array}{c}2, \% \\
\overline{b_{1}} \wedge b_{2}\end{array}$ & $\begin{array}{c}3, \% \\
b_{1} \wedge b_{2}\end{array}$ & $\begin{array}{c}4, \% \\
\overline{b_{1}} \wedge \overline{b_{2}}\end{array}$ \\
\hline 1 & $t_{0.25}^{X}$ & 3,6 & 16,1 & 79,5 & 0,1 \\
\hline 2 & $t_{0.50}^{X}=$ median $^{X}$ & 16,6 & 34,0 & 48,4 & 1,0 \\
\hline 3 & mean $^{X}$ & 26,7 & 41,0 & 25,2 & 7,1 \\
\hline 4 & $t_{0.75}^{X}$ & 27,8 & 34,7 & 12,8 & 24,5 \\
\hline
\end{tabular}

Таких вагонів виявилось 858. Частка вагонів, затримку яких спричинила тільки одна залізниця, становить від $19,7 \%$ до $67,7 \%$.

\section{ВИСНОВКИ}

Інформаційна система, що функціонує наразі на залізниці, дозволяє вирахувати обіг вагона за кожним його номером, за певними характеристиками перевезення та визначити час знаходження рухомого складу на структурному підрозділі при виконанні всього циклу роботи.

Статистичні дослідження показали наступне: 
-тривалість обігу залежить від багатьох факторів, зокрема змінюється на протязі року , в залежності від місяця року; залізниці

-складові циклу - час знаходження на залізницях, суттєво відрізняються в залежності від

-зі структури вибірки вагонів випливає, що відповідальність за перевищення «середньої норми» знаходження вагонів однозначно ідентифікується.

Попередні висновки підтверджуються — керуючий/мотиваційний вплив на залізницю має співвідноситись із обсягами вагонів типу 1 , типу 2 , мабуть і типу 3 , тобто ідентифікованим внеском у збільшення часу обігу порівняно з типовою статистикою.

Використання зазначених положень дасть можливість відійти від умовного визначення обігу за формулами, що використовують балансовий метод та застосовувати сучасні статистичні методи для визначення обігу вагонів як характеристики певного перевезення.

Для визначення нормативного та фактичного обігу вагонів, а також прийняття оперативних заходів управління запропоновано аналізувати час знаходження його на кожному підрозділі (залізниці) за даними інформаційної системи. Це дозволить встановлювати реальні норми обігу вагонів та терміни доставки вантажів, що забезпечать дотримання технологічних процесів експлуатаційної роботи залізниці при обслуговуванні клієнтів.

\section{ПЕРЕЛІК ДЖЕРЕЛ ПОСИЛАННЯ}

1. Improvement of the technique of calculating operational parameters using an automated system / Y. Statyvka, H. Kyrychenko, O. Strelko [та ін.] // MATEC Web of Conferences. 2019. № 294. P. 06002 https://doi.org/10.1051/matecconf/201929406002

2. Розпорядження кабінету міністрів України «Про схвалення Національної транспортної стратегії України на період до 2030 року» від 30 травня 2018 року № 430-р. / Верховна Рада України. URL: https://zakon.rada.gov.ua/laws/show/430-2018-\%D1\%80\#Text (дата звернення: 12.03.2021).

3. Steel product transportation and storage simulation: A combined simulation/optimization approach, / N. Ueno, Y. Nakagawa, S. Morito, Y. Okuno // 1988 Winter Simulation Conference Proceedings. San Diego, CA, USA, 1988. P. 678-683.

4. Макаренко М. В. Краткий справочник показателей эксплуатационной работы железных дорог Украины. Киев: «Юникон-Прес», 2001. 154 с.

5. Богомазова Г. Є. Формування автоматизованої технології управління вагонопотоками на залізничних напрямках: автореферат дис. ... канд. тех. наук: 05.22.20. Харків, 2019. 22 с.

6. Распоряжение ОАО "РЖД" от 18.08.2015 N 2075p «Об утверждении «Методики технического нормирования, учета рабочего парка и времени оборота грузового вагона на инфраструктуре общего пользования» и установлении статистического наблюдения за показателями использования грузовых вагонов на инфраструктуре общего пользования». Москва: ОАО «РЖД», 2015. C. $14-17$.

7. Kozachenko D., Bobrovskyi V., Demchenko Y. A method for optimization of time intervals between rolling cuts on sorting humps. Journal of Modern Transportation. 2018. №26(3). P. 189-199.

8. Zinder E. Z. SUBD i deystvitelno bolshie sistemyi. Sistemyi upravleniya bazami dannyih: elektron. versiya zhur (Aug. 2018). URL: https://www.osp.ru/news/articles/1997/0801/13031555\#part_1 (дата звернення: 12.03.2021).

9. Wang F. Y. Toward a revolution in transportation operations: AI for complex systems. Intelligent Systems: IEEE. 2008. № 23 (6). P. 8-13. https://doi.org/10.1109/MIS.2008.112

10. Application of Information Technologies for Automation of Railway and Cargo Owner Interaction / O. H. Strelko, H. I. Kyrychenko, Yu. A. Berdnychenko [et al.] // Materials Science and Engineering. 2019. № 582 (1). Р. 012029.

11. Алгоритмы оптимизации в задачах планирования на рельсовом транспорте/ Н. А.Кузнецов, Ф. Ф. Пащенко, Н. Г. Рябых [и др.] // Информачионные проиессы. 2014. Том 14, № 4. С. 307-318.

12. Моделювання сценаріїв переміщення вантажу у ланцюгах доставки / Н. I. Kyrychenko, О. Н. Strelko, Yu. A. Berdnychenko [та ін.] // Транспортні системи та технології перевезень. 2016. № 12. С. 32-37. https://doi.org/10.15802/tstt2016/85882.

13. Noia Di, Semantic T. Matchmaking as Non-Monotonic Reasoning A. Description Logic Approach. Journal of Artificial Intelligence Research. 2007. №29. P. 269-307.

14. Dávid A. Innovation of handling systems in the world container ports and their terminals Proceedings of the 17th International Conference Transport Means 2013. (Kaunas: University of 
Technology, 2013). Kaunas, 2013. P. 250-253

15. Petrashevsky O. L., Redzyuk A. M. Alekseenko O. V. Methodology of conceptual-logistic mapping and project modeling of the objectives of the traffic safety management system NTU. Collection of Scientific Articles. 2009. № 6(10). C. 76-89.

16. Іващук В. Р. Формування інструментів логістичного забезпечення перевезень вантажів на залізниці. Залізничний транспорт Украӥни. 2011. №5. С. 20-23.

17. Marinov M., Zunder T., Mortimer P. Rail Freight Services. World Transport, Policy \& Practice. 2012. № 18(2). P. 30-38.

\section{REFERENCES}

1. Statyvka, Y., Kyrychenko, H., Strelko, O., Berdnychenko, Y., Haba, V., Hrushevska, T. (2019). Improvement of the technique of calculating operational parameters using an automated system. MATEC Web of Conferences, 294(6), 06002. https://doi.org/10.1051/matecconf/201929406002

2. Pro skhvalennia Natsionalnoi transportnoi stratehii Ukrainy na period do 2030 roku: Rozporiadzhennia Kabinetu ministriv Ukrainy vid 30 travnia 2018 r. № 430-r. 2018. [ On approval of the National Transport Strategy of Ukraine for the period up to 2030: Order of the Cabinet of Ministers of Ukraine from May 30, 2018 № 430-r. 2018.]. Verkhovna Rada Ukrainy. Retrieved from: https://zakon.rada.gov.ua/laws/show/430-2018-\%D1\%80\#Text [in Ukraine].

3. Ueno, N., Nakagawa, Y., Morito, S., Okuno, Y. (1988). Steel product transportation and storage simulation: A combined simulation/optimization approach. 1988 Winter Simulation Conference Proceedings. San Diego, CA, USA.

4. Makarenko, M. V. (2001). Kratkiy spravochnik pokazateley ekspluatatsionnoy rabotyi zheleznyih dorog Ukrainyi. Kiev: Iunikon-Press [in Russia].

5. Bohomazova, H. Ye. (2019). Formuvannia avtomatyzovanoi tekhnolohii upravlinnia vahonopotokamy na zaliznychnykh napriamkakh: avtoreferat dys. ... kand. tekh. nauk: 05.22.20 [Formation of automated technology of car traffic control on railway directions]. Kharkiv [in Ukraine].

6. Rasporiazhenie OAO "RZhD" ot 18.08.2015 N 2075r «Ob utverzhdenii «Metodiki tekhnicheskogo normirovaniia, ucheta rabochego parka i vremeni oborota gruzovogo vagona na infrastrukture obshchego polzovaniia» $\mathrm{i}$ ustanovlenii statisticheskogo nabliudeniia za pokazateliami ispolzovaniia gruzovykh vagonov na infrastrukture obshchego polzovaniia» [Order of JSC "Russian Railways" of August 18, 2015 N 2075r "On approval of the" Methodology for technical regulation, accounting of the working fleet and turnover time of a freight car on public infrastructure "and the establishment of statistical monitoring of indicators of the use of freight cars on public infrastructure]. Moskva: OAO «RZhD», 2015 [in Russia].

7. Kozachenko, D., Bobrovskyi, V., Demchenko, Y. A. (2018). Method for optimization of time intervals between rolling cuts on sorting humps. Journal of Modern Transportation, 26(3), 189-199.

8. Zinder, E. Z. SUBD i deystvitelno bolshie sistemyi. Sistemyi upravleniya bazami dannyih: elektron. versiya zhur (Aug. 2018). Retrieved from: https://www.osp.ru/news/articles/1997/0801/13031555\#part_1.

9. Wang, F. Y. (2008). Toward a revolution in transportation operations: AI for complex systems. Intelligent Systems: IEEE, 23 (6), 8-13. https://doi.org/10.1109/MIS.2008.112

10. Strelko, O. H., Kyrychenko, H. I., Berdnychenko, Y. A., Sorochynska, O. L., Pylypchuk, O. Y. (2019). Application of Information Technologies for Automation of Railway and Cargo Owner Interaction. IOP Conference Series: Materials Science and Engineering, 582 (1), 012029.

11. Kuznetcov, N. A., Pashchenko, F. F., Riabykh, N. G., Zakharova, E. M., Minashina, I. K. (2014). Algoritmy optimizatcii $\mathrm{v}$ zadachakh planirovaniia na relsovom transporte [Design and analysis of optimization algorithm for multi-agent rail control system]. Informatcionnye protcessy, 14(4), 307-318. [in Russia].

12. Kyrychenko, H. I., Strelko, O. H., Berdnychenko, Yu. A., Petrykovets, O. V., Kyrychenko, O. A. (2016). Modeliuvannia stsenariiv peremishchennia vantazhu u lantsiuhakh dostavky [Scenarios modeling of cargo movement in the supply chains]. Transportni systemy ta tekhnolohii perevezen, 12, 32-37. https://doi.org/10.15802/tstt2016/85882 [in Ukraine].

13. Noia, Di, Semantic, T. (2007). Matchmaking as Non-Monotonic Reasoning A. Description Logic Approach. Journal of Artificial Intelligence Research, 29, 269-307.

14. Dávid, A. (2013). Innovation of handling systems in the world container ports and their terminals. Proceedings of the 17th International Conference Transport Means 2013. Kaunas: University of Technology.

15. Petrashevsky, O. L., Redzyuk, A. M. Alekseenko, O. V. (2009). Methodology of conceptuallogistic mapping and project modeling of the objectives of the traffic safety management system NTU. 
Collection of Scientific Articles, 6(10), 76-89.

16. Ivashchuk, V. R. (2011). Formuvannia instrumentiv lohistychnoho zabezpechennia perevezen vantazhiv na zaliznytsi [Formation of tools for logistical support of freight transportation by rail]. Zaliznychnyi transport Ukrainy, 5, 20-23. [in Ukraine].

17. Marinov, M., Zunder, T., Mortimer, P. (2012). Rail Freight Services. World Transport, Policy \& Practice, 18(2), 30-38.

\section{H. Kyrychenko, Yu. Berdnychenko, O. Strelko: Advances in technology for calculating operational work indicators using an automated system}

In the context of the transport market development, the key issues for the railway transportation system are: timely provision of wagons of the appropriate type to all consignors in accordance with their orders; further consolidation of railway transport in the transportation market through the marketing development, the creation of a balanced tariff policy; improving the organizational structures of railway transport management, the technology of the transportation process and the organization of transportation work on the basis of the widespread introduction of automated control systems. The purpose of the article is to study the possibility of increasing the efficiency of using the wagons fleet, related to this the goods delivery time compliance, based on a new methodology and calculation principle. One of the main aggregated factors of the railway operation is the wagon turnover which reflects the time of the wagon's full cycle operation. Now the turnover of wagon is increasing, for the railway this means non-compliance with the established norms, for the services recipients - the railway customers - this means delays in the delivery of goods, violation of financial obligations to other participants in the transportation process. Information technologies on the railway provide for the possibility of monitoring the fulfillment of the standard for the wagons turnover and the observance of the cargo delivery time with further improvement of the methods and techniques for determining the operational work indicators. An increase in the efficiency of using the fleet of wagons, related to this the delivery time compliance, due to the new methodology and principle of calculating and forecasting the main performance indicators, has been investigated. Possibilities to deviate from the conventional definition of the wagons turnover by formulas, which use the balance method, and to apply modern statistical methods to determine the turnover of wagons as a characteristic of certain transportation have been analyzed. This will allow to set real standards for the wagons turnover and the terms of goods delivery, which will ensure compliance with the technological processes of the operational work of the railway when servicing customers. railway.

Key words: information technologies, delivery terms, wagons turnover, technological process,

КИРИЧЕНКО Ганна Іванівна, кандидат технічних наук, доцент кафедри технологій транспорту та управління процесами перевезень, Державний університет інфраструктури та технологій e-mail: babichanya@ukr.net. https://orcid.org/0000-0002-6883-1877

БЕРДНИЧЕНКО Юлія Анатолї̈вна, кандидат історичних наук, доцент кафедри технологій транспорту та управління процесами перевезень, Державний університет інфраструктури та технологій e-mail: yb08@ukr.net. https://orcid.org/0000-0001-7536-7155

СТРЕЛКО Олег Григорович, доктор історичних наук, професор кафедри технологій транспорту та управління процесами перевезень, Державний університет інфраструктури та технологій е-таil: olehstrelko@gmail.com. https://orcid.org/0000-0003-3173-3373

Hanna KYRYCHENKO, Ph.D., Associate Professor at the Department of Transport Technologies and Transportation Processes Operation, State University of Infrastructure and Technologies e-mail: babichanya@ukr.net. https://orcid.org/0000-0002-6883-1877

Yuliia BERDNYCHENKO, Ph.D., Associate Professor at the Department of Transport Technologies and Transportation Processes Operation, State University of Infrastructure and Technologies e-mail: yb08@ukr.net. https://orcid.org/0000-0001-7536-7155

Oleh STRELKO, Doctor of Historical Sciences, Professor at the Department of Transport Technologies and Transportation Processes Operation, State University of Infrastructure and Technologies email: olehstrelko@gmail.com. https://orcid.org/0000-0003-3173-3373

DOI 10.36910/automash.v2i17.637 